\title{
The Constraint of the Eco-Friendly Rooftop PV System Implementation Based on the Techno- Economic and Regulatory Impact Analysis: Case Study of the Ontowiryo Mosque in Purworejo, Central Java, Indonesia
}

Woko - Suparwoko ( $\square$ suparwoko@uii.ac.id) Islamic University of Indonesia: Universitas Islam Indonesia https://orcid.org/0000-0002-9977-0325

Fadhil Ahmad Qamar

Smart Energy Indonesia

Research

Keywords: PV System, Mosque Rooftop, Power Regulation, Techno-economic Analysis

Posted Date: March 5th, 2021

DOI: https://doi.org/10.21203/rs.3.rs-265719/v1

License: (c) (1) This work is licensed under a Creative Commons Attribution 4.0 International License.

Read Full License 
The Constraint of the Eco-Friendly Rooftop PV : System Implementation Based on the

${ }^{*}$ Correspondence:

suparwoko@uii.ac.id

${ }^{1}$ Department of Architecture,

Universitas Islam Indonesia,

Yogyakarta, Indonesia

Full list of author information is available at the end of the article

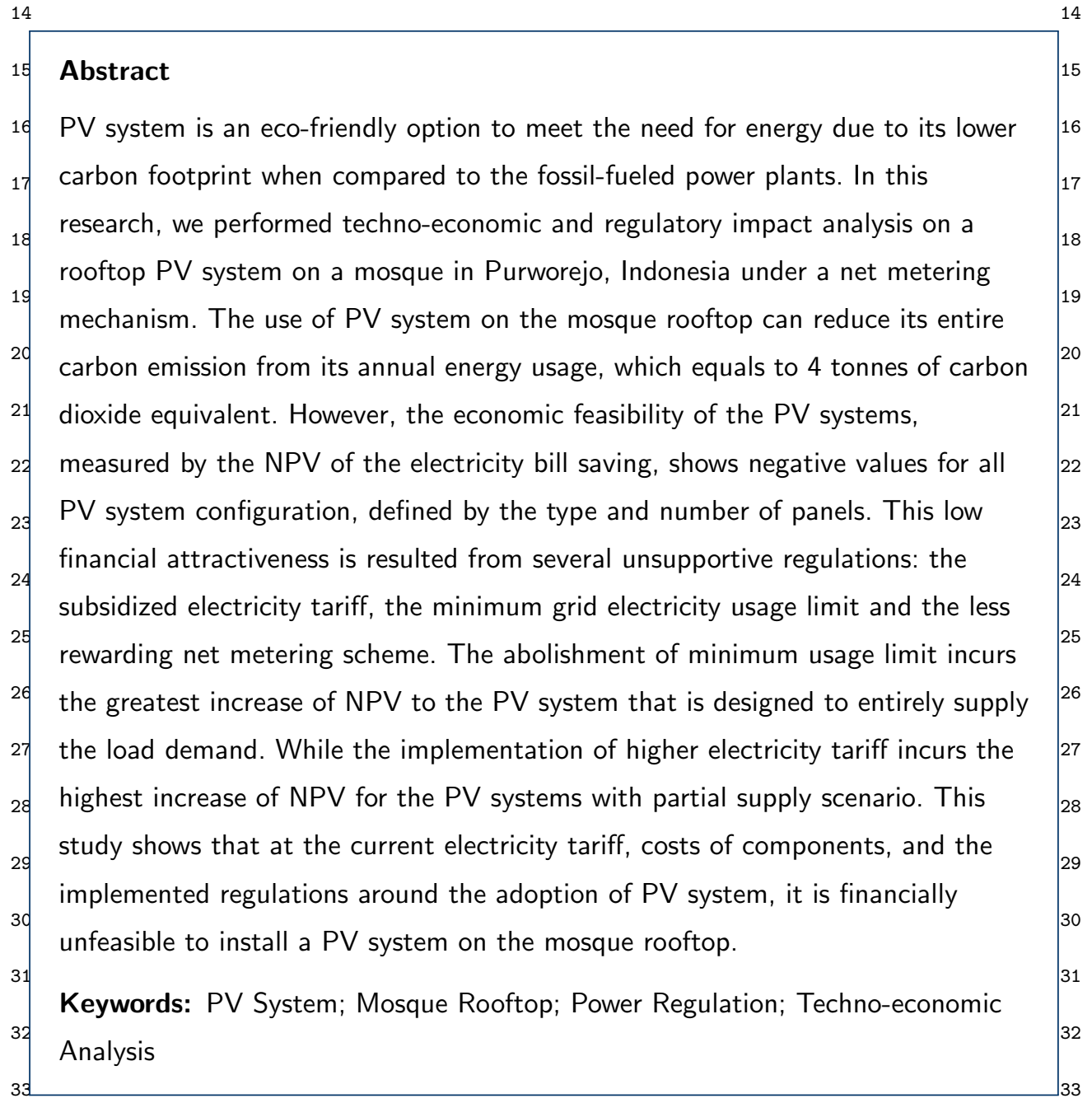


${ }^{1} \mathbf{1}$ Introduction ${ }^{1}$

${ }^{2}$ In order to tackle the climate change, Indonesia has planned to increase its energy ${ }^{2}$

${ }^{3}$ mix for electricity production from renewable energy by $23 \%$ in 2025 [1]. Until the ${ }^{3}$

${ }^{4}$ first semester of 2020, DEN [2] reported that the share of renewable energy for elec- ${ }^{4}$

${ }^{5}$ tricity generation has only reached $10.9 \%$. Renewable energy, including solar energy,

${ }^{6}$ is eco-friendly and can be utilized for generating power with carbon footprint lower ${ }^{6}$

${ }^{7}$ than those of the fossil fueled power plants. Tawalbeh et al. [3] estimated that the ${ }^{7}$

8 carbon footprint from PV systems was in the range of $14-73 \mathrm{~g} \mathrm{CO} 2-\mathrm{eq} / \mathrm{kWh}$, which ${ }^{8}$

${ }^{9}$ is only 2 to $10 \%$ of the carbon emitted to generate $1 \mathrm{kWh}$ of electricity by burning ${ }^{9}$

10 the oil.

${ }^{11}$ On the other hand, through their studies, IESR [4] suggested that Indonesia can ${ }^{11}$

${ }^{12}$ achieve the energy transition goal by utilizing the distributed generation of solar ${ }^{12}$

${ }^{13}$ power in the form of rooftop and off grid PV system. It is estimated that there is ${ }^{13}$

${ }^{14}$ at least a potential of $2 \mathrm{GWp}$ rooftop solar PV in the residential market of Jakarta ${ }^{14}$

${ }^{15}$ and Surabaya. Hence, it is implied that a greater potential is expected when more ${ }^{15}$

16 cities and other type of buildings are considered. 16 cities and other type of buildings are considered.

${ }^{17}$ For this reason, this paper aims to explore the design and feasibility of rooftop $\mathrm{PV}^{17}$

18 system. The case study considered in this paper is the rooftop solar PV of mosque, ${ }^{18}$

19 specifically the Ontowiryo Mosque in Purworejo, Central Java [5]. The choice of ${ }^{19}$

${ }^{20}$ mosque as the case study is also supported by the fact that Indonesia is one of the ${ }^{20}$

${ }^{21}$ countries with the largest population of Muslims. To support their activities, Min- ${ }^{21}$

${ }^{22}$ istry of Religion [6] reported that Indonesia has more than half a million of mosques ${ }^{22}$

${ }^{23}$ and prayer halls with various sizes. Ghazali et al. [7] stated in their book that the ${ }^{23}$

24 use of clean energy in such facility is also relevant ethically and morally since the 24

25 reservation of the nature and environment is one of the teachings of Islam. 25 preservation of the nature and environment is one of the teachings of Islam.

${ }^{26}$ The commandment for humanity to utilize solar energy is also implicitly stated in ${ }^{26}$

${ }^{27}$ the Holy Quran, the holy book of Islam. This order is stated in the first verse of

${ }^{28}$ Chapter 108 that says: "Surely We have given thee abundance of good" [8]. Through ${ }^{28}$

${ }^{29}$ this verse, the muslims believe that God Almighty has given an abundance of good- ${ }^{29}$

${ }^{30}$ ness to humanity through the manifestation of the universe that includes the earth, ${ }^{30}$

31 sun and stars, and so on to provide for the sustainability of the humanity. Fur- 31

${ }^{32}$ thermore, some of the main purposes of the sun is to illuminate the earth with its ${ }^{32}$

${ }^{33}$ rays and provide an immense source of energy. For that reason, until now, human- ${ }^{33}$ 
${ }^{1}$ ity keeps exploring the benefits that can be utilized from the use of solar energy. ${ }^{1}$

${ }^{2}$ This argument also serves as one of the underlying reasoning for conducting this ${ }^{2}$

${ }^{3}$ research, that is, to explore the utilization of solar energy through the PV system on ${ }^{3}$

${ }^{4}$ the rooftop of Ontowiryo Mosque in Purworejo, Indonesia for the lighting purposes ${ }^{4}$

${ }^{5}$ of the mosque and the neighborhood. 5

${ }^{6}$ There has been a significant number of researches on the implementation of rooftop ${ }^{6}$

${ }^{7}$ solar PV for mosques, as will be briefly discussed in this paper. Rashid et al. [9] ${ }^{7}$

${ }^{8}$ analyzed mosque rooftop PV system could reduce the electricity bill annually by ${ }^{8}$

${ }^{9} 47 \%$ in Malaysia. The result shows that the payback period of the PV system's ${ }^{9}$

${ }^{10}$ initial investment is reached in 13 years. Similar study was performed in Kuwait ${ }^{10}$

${ }^{11}$ which resulted the same payback period. Almutairi [10] investigated the financial ${ }^{11}$

${ }^{12}$ feasibility of rooftop solar PV system at 1400 mosques in Kuwait is studied in 2018. ${ }^{12}$

${ }^{13}$ The PV systems are designed to supply the connected load and shave the peak load ${ }^{13}$

${ }^{14}$ during the day. Both studies however did not consider the present value of future ${ }^{14}$

${ }^{15}$ cashflows. Thus, the benefit of the rooftop PV systems is subject to overestimation ${ }^{15}$

${ }^{16}$ and the real payback period may be achieved at a later date. 16

${ }^{17}$ In 2019, Elshurafa et al. [11] conducted a more comprehensive pilot study of mosque ${ }^{17}$

${ }^{18}$ rooftop PV system in Saudi Arabia. The PV system studied is connected to the grid ${ }^{18}$

${ }^{19}$ for different scenarios: no support policy and with net-metering mechanism which ${ }^{19}$

${ }^{20}$ enables the compensation for the exported surplus-generation to the grid. The study ${ }^{20}$

${ }^{21}$ finds that the analyzed system is financially attractive for both scenarios. The im- ${ }^{21}$

${ }^{22}$ plementation of net-metering reduces the cost incurred for fulfilling electricity needs ${ }^{22}$

${ }^{23} 22 \%$ lower than the rooftop PV system with no support policy scenario. ${ }^{23}$

${ }^{24}$ As of 2018, the government of Indonesia [12] have ratified the latest regulation on ${ }^{24}$

${ }^{25}$ the net metering scheme for solar rooftop. Therefore, this paper aims to perform ${ }^{25}$

${ }^{26}$ a similar study to the previously mentioned related papers, that is to explore the ${ }^{26}$

${ }^{27}$ design and feasibility of mosque rooftop PV system with a case study location in $^{27}$

${ }^{28}$ Indonesia. $\quad 28$

${ }^{29}$ To that end, we present for the first time a detailed techno-economic analysis of ${ }^{29}$

${ }^{30}$ mosque rooftop PV system in Indonesia. The result of this study serves twofold pur- ${ }^{30}$

${ }^{31}$ poses. First, it would provide the definition of rooftop PV system on the mosque ${ }^{31}$

${ }^{32}$ considered in the case study, in Indonesia. Second, it would provide insights to ${ }^{32}$ 
${ }^{1}$ policymakers on the effectiveness of the current supporting policy for the imple- ${ }^{1}$

${ }^{2}$ mentation of the rooftop PV system for a specific type of end-user.

2

3

${ }_{4} 2$ Methods

${ }_{5}$ To achieve the research goals, three main activities are conducted in this research:5 ${ }_{6}$ data acquisition, rooftop PV system design and simulation, and design result anal-6 7ysis. The analyses in each activity are done with using codes written in MATLAB.7

8

2.1 Data Acquisition 10 sign process, which includes site condition data and hourly electricity load profile ${ }_{12}$ data. The site condition data are obtained from Solcast [13] Toolkit which provide a comprehensive set of hourly site condition data that includes air temperature, cloud opacity, solar irradiance (DHI, DNI and GHI), sun azimuth angle, sun alti14 15 16 ${ }_{17}$ sample of electricity consumption in one day. This method is unavailable for the ${ }_{18}$ considered case study as the mosque is currently under construction. Therefore, the ${ }_{18}$ load profile of the mosque is estimated by calculating the lighting and electronic 19 equipment that is possibly used for certain activities and at certain times. To con${ }_{21}$ clude, this research work with 8784 hourly data to simulate a full year operation of ${ }_{21}$ rooftop PV system.

${ }^{23} 2$ Rouftop PV System Design 23

24

${ }^{24}$ The solar irradiance received by the rooftop area arrives in three forms: direct ${ }^{24}$ ${ }^{25}$ and diffused irradiance and the irradiance reflected by the ground [14]. The solar ${ }^{25}$ ${ }^{26}$ irradiance data obtained in the previous activity are used to calculate each value ${ }^{26}$ ${ }^{27}$ of these forms, which are then summed to determine the irradiance received by the ${ }^{27}$ $28 \quad 28$ rooftop and, hence, the estimated yield of solar energy on the mosque roof.

${ }^{29}$ This paper studied a grid connected PV system. The optimal number of solar panels ${ }^{29}$

${ }^{30}$ and inverter capacity in the PV systems are determined by modeling the PV system ${ }^{30}$

${ }^{31}$ using the solar radiation data and the electrical load profile as the input. This paper ${ }^{31}$

32 employs two design scenarios: complete and partial fulfillment of load demand by ${ }^{32}$

${ }^{33}$ the PV systems which will be referred as the first and second scenario respectively ${ }^{33}$ 
${ }^{1}$ in this paper.

${ }^{2}$ In Indonesia, a monthly minimum limit of electricity usage as much as 40 hours of ${ }^{2}$

${ }^{3}$ consumption at maximum power limit are imposed to the grid-connected user [15]. ${ }^{3}$

${ }^{4}$ Thus, the partial scenario entails a combination of the PV system and the grid to ${ }^{4}$

${ }^{5}$ supply the load demand. The grid supplies the load demand under the minimum ${ }^{5}$

${ }^{6}$ limit, while the PV system supply the excess. 6

${ }^{7}$ At each hourly time steps, if the electricity supply from the PV system is smaller ${ }^{7}$

${ }^{8}$ than the load demand, the electricity load will be met by electricity from the $\mathrm{PV}^{8}$

${ }^{9}$ system while importing the mismatch from the grid. Thus, the load demand met ${ }^{9}$

${ }^{10}$ by the PV system during this condition is equal to the PV system generation. Vice ${ }^{10}$

${ }^{11}$ versa, when the electricity supply from the PV system is greater than the electricity ${ }^{11}$

${ }^{12}$ load at a certain time, the electricity load will be completely supplied by the $\mathrm{PV}^{12}$

${ }^{13}$ system and excess electricity from the PV system will be exported to the grid. 13

14

${ }^{15} 2.3$ Design Result Analysis

${ }^{16}$ The design result analysis incorporates the calculation of carbon emission reduction ${ }^{16}$

${ }^{17}$ and financial feasibility study of the PV system. The benefit of carbon emission ${ }^{17}$

${ }^{18}$ reduction is then translated in monetary terms by using the social cost of carbon ${ }^{18}$

${ }^{19}$ emission so that it can be easily compared with the financial feasibility study. The ${ }^{19}$

${ }^{20}$ financial feasibility study was conducted using the analysis of Net Present Value ${ }^{20}$

${ }^{21}(\mathrm{NPV})$ and Levelized Cost of Electricity (LCOE). 21

22

${ }^{25}$ The NPV is calculated by using the Equation 1 with $R_{t}$ represents the cashflow,25 26in and out, in year $t$ with a discount factor $i$. The cash outflow accounts the initial26 27investment and annual operation and maintenance cost. While the cash inflow is 27 ${ }^{28}$ defined as the annual electricity bill reduction. Thus, the NPV value in this paper28 ${ }^{29}$ regards the present value of the electricity bill savings [14]. This metrics also indicate29 30the recovery rate of capital expenditure (CAPEX), with zero NPV means full capital30

${ }^{31}$ expenditure recovery. 31 
${ }^{1} \mathrm{LCOE}$ is calculated by using Equation (2) with OPEX is the operational and main- ${ }^{1}$ ${ }^{2}$ tenance expenditure, and $P V_{u t i l}$ is the energy generated by the PV system that can ${ }^{2}$ ${ }^{3}$ be utilized by the mosque. The financial feasibility analysis is followed by a sensi- ${ }^{3}$ ${ }^{4}$ tivity analysis on the impact of different regulations implementation. The change ${ }^{4}$ ${ }^{5}$ of the PV systems' NPV is used as the metric to measure the impact of the change ${ }^{5}$ ${ }^{6}$ in regulation.

\section{Case Study and Assumption}

\subsection{Site Information}

10 The Ontowiryo Mosque is located on the south side of Purworejo district, Central ${ }^{10}$

${ }^{11} \mathrm{Java}$, at $109.96^{\circ}$ Longitude, $-7.85^{\circ}$ Latitude. The specification of the roof is shown ${ }^{11}$

${ }^{12}$ in figure 1 . The mosque is connected to the grid with a maximum power limit of ${ }^{12}$

13

13
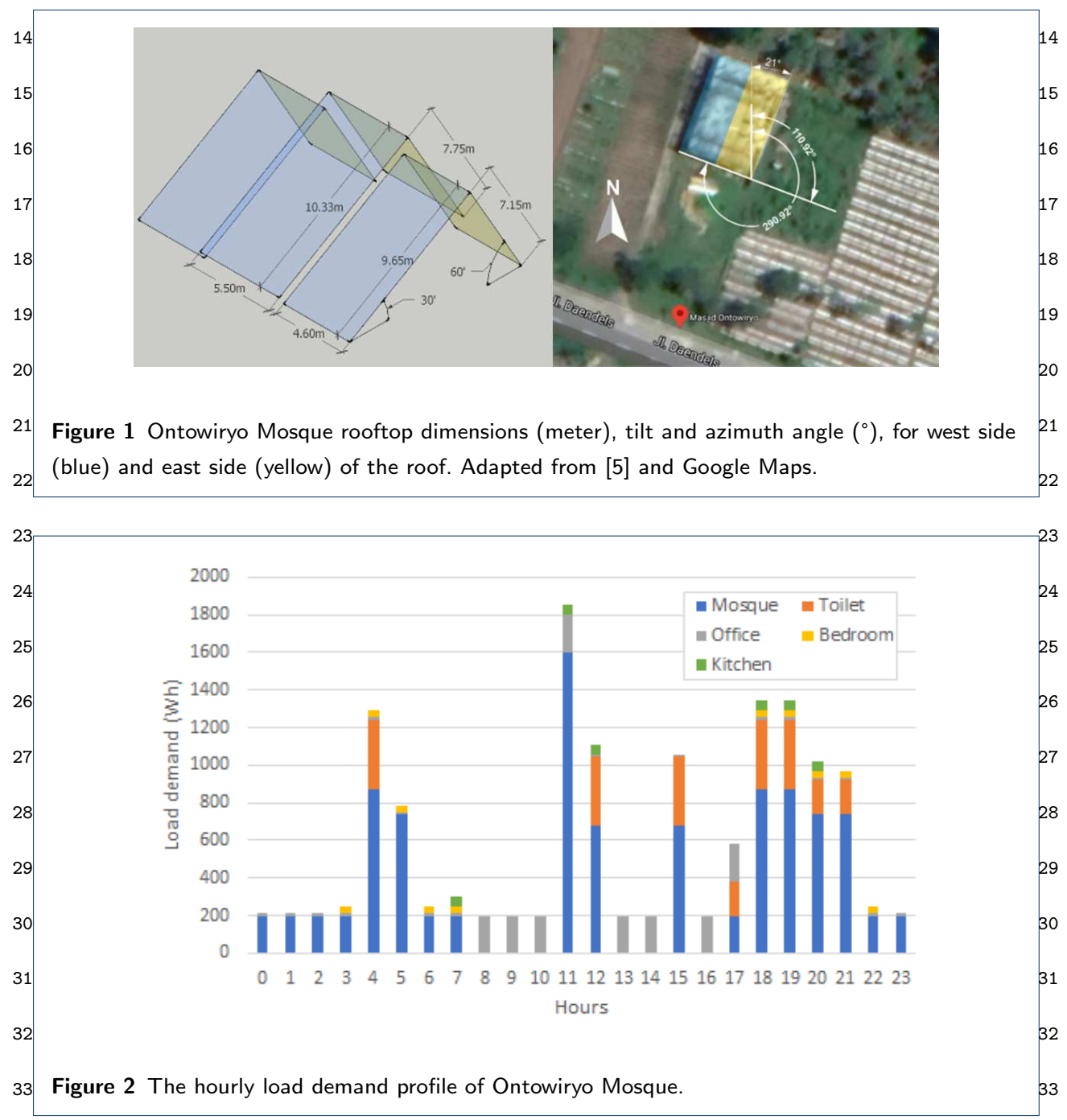
${ }^{1} 5500$ VA. As shown in figure 2, the electricity load demand are concentrated during ${ }^{1}$ ${ }^{2}$ prayer times and the cleaning period of the mosque at 11 AM. Muslims pray in ${ }^{2}$ ${ }^{3}$ congregation at the mosque 5 times a day: before dawn, at noon, in the afternoon, ${ }^{3}$ ${ }^{4}$ at sunset and after dusk. Outside these periods, the load profile of the mosque is ${ }^{4}$ ${ }^{5}$ relatively constant with an electrical load of \pm 200 Wh for lighting purposes. The ${ }^{5}$ ${ }^{6}$ daily profile of the electricity load is assumed to be identical for one year due to the ${ }^{6}$ ${ }^{7}$ recurring nature of the activities. In total, the daily and annual electricity loads of ${ }^{7}$ ${ }^{8}$ the Ontowiryo Mosque are, respectively, $14.42 \mathrm{kWh}$ and $5278.63 \mathrm{kWh} . \quad{ }^{8}$

${ }^{10} 3.2$ Financial and Operational Assumption 10

${ }^{11}$ To ensure the validity of the data and to simplify the comparison of different types ${ }^{11}$ ${ }^{12}$ of solar panels, the data for solar panels are taken from a website of renewable en- ${ }^{12}$ ${ }^{13}$ ergy technology distributor, windandsun.co.uk. The website provides 15 solar panels ${ }^{13}$ ${ }^{14}$ from 3 different manufacturers: 9 REC panels (TwinPeak, Alpha and N-peak se- ${ }^{14}$ ${ }^{15}$ ries), 4 LG panels (NeON and NeON2 series) and 2 Solarwatt panels (High Power ${ }^{15}$ ${ }^{16}$ and Eco series). Apart from the solar panel, capital expenditure (CAPEX) of the ${ }^{16}$ ${ }^{17} \mathrm{PV}$ system also includes inverter, mounting structure, component's shipping cost, ${ }^{17}$ 18 civil work and cabling. ${ }^{20}$ erage capital cost (WACC). IRENA [16] assumes a real WACC of $7.5 \%$ in OECD ${ }^{20}$ ${ }^{21}$ countries and China, and $10 \%$ for elsewhere in the world for all types of technology. ${ }^{21}$ ${ }^{22}$ Meanwhile, the IEA [17], on the other hand, assumes a WACC of $8 \%$ in developed ${ }^{22}$ ${ }^{23}$ countries and $7 \%$ in developing countries. Steffen [18] estimated the WACC for $\mathrm{PV}^{23}$ ${ }^{24}$ system development projects in and outside of the OECD countries were $5.4 \%$ and $^{24}$ ${ }^{25} 7.4 \%$. This paper employs a WACC level at $7 \%$.

${ }^{26}$ The 2019 PLN statistics [19], which provide data on the average electricity tariff ${ }^{26}$ ${ }^{27}$ per customer group in 2011 to 2019 , are used to determine the electricity tariff used ${ }^{27}$ ${ }^{28}$ in this paper. The existing electricity tariff data are then extrapolated to estimate ${ }^{28}$ ${ }^{29}$ the future electricity tariff over the lifetime of the PV system project or up to $2045{ }^{29}$ 30 hown in figure 3. Over the 25-years of the assumed lifespan of the PV system 30 ${ }^{31}$ electricity tariffs are expected to increase by $60 \%$, with an estimated tariff at IDR ${ }^{31}$ ${ }^{32} 913 / \mathrm{kWh}$ in 2021 and IDR $1,450 / \mathrm{kWh}$ in 2045. The tariff for customer in social ${ }^{32}$ 33 sector is subsidized. 


\section{${ }^{1} 4$ Result}

${ }^{2} 4.1$ PV System Configuration 2

${ }^{3}$ The site condition analysis shows that the solar irradiance potential in the case ${ }^{3}$ ${ }^{4}$ study location is at $1971 \mathrm{kWh} /$ year.m2 or equals to 5.4 daily Equivalent Sun Hours ${ }^{4}$ ${ }^{5}(\mathrm{ESH})$. This potential is achieved with an optimal configuration of solar panel tilt ${ }^{5}$ ${ }^{6}$ angle and azimuth at $10^{\circ}$ and $6^{\circ}$, respectively, as shown in figure 4 . Consequently, as ${ }^{6}$ ${ }^{7}$ the existing roof orientation is different from the optimal configuration, the potential ${ }^{7}$ ${ }^{8}$ of solar irradiance in each sides of the roof, west and east, are at 4.9 and $3.5 \mathrm{ESH}^{8}$ ${ }^{9}$ When entire area of the roof is considered, the total potential for the west and east ${ }^{9}$ ${ }^{10}$ side of the roof are respectively at 263.24 and 141.47 MWh annually. 10 11

${ }_{13}$ The result of the performance analysis shows that the PV system efficiency ranges ${ }_{13}$ ${ }_{14}$ from $15.6 \%$ to $19.37 \%$, and energy yield ranges from 1216 to $1263 \mathrm{kWh} / \mathrm{kWp}$ in $\mathrm{a}_{14}$ 15year. PV system using REC AA series panel achieved the highest system efficiency ${ }_{15}$ ${ }_{16}$ and solar energy yield due to their high panel efficiency. ${ }_{17}$ The result also shows that the capacity of the PV system ranges from $4020 \mathrm{Wp}_{17}$ ${ }_{18}$ to $4615 \mathrm{Wp}$ to completely meet the load demand. With this capacity, at least ${ }_{18}$ ${ }_{19}$ around $25 \%$ of the generated electricity is lost in the grid during the export and ${ }_{19}$ ${ }_{20}$ import process. The net-metering scheme in Indonesia only compensates $65 \%$ of the ${ }_{20}$ ${ }_{21}$ exported energy. Hence, a smaller amount generated electricity leads to a smaller ${ }_{21}$ ${ }_{22}$ amount of exported electricity in the grid, and, thus smaller losses. ${ }_{23}$ For the same reason, the PV system in the second design scenario has a lower $\operatorname{grid}_{23}$

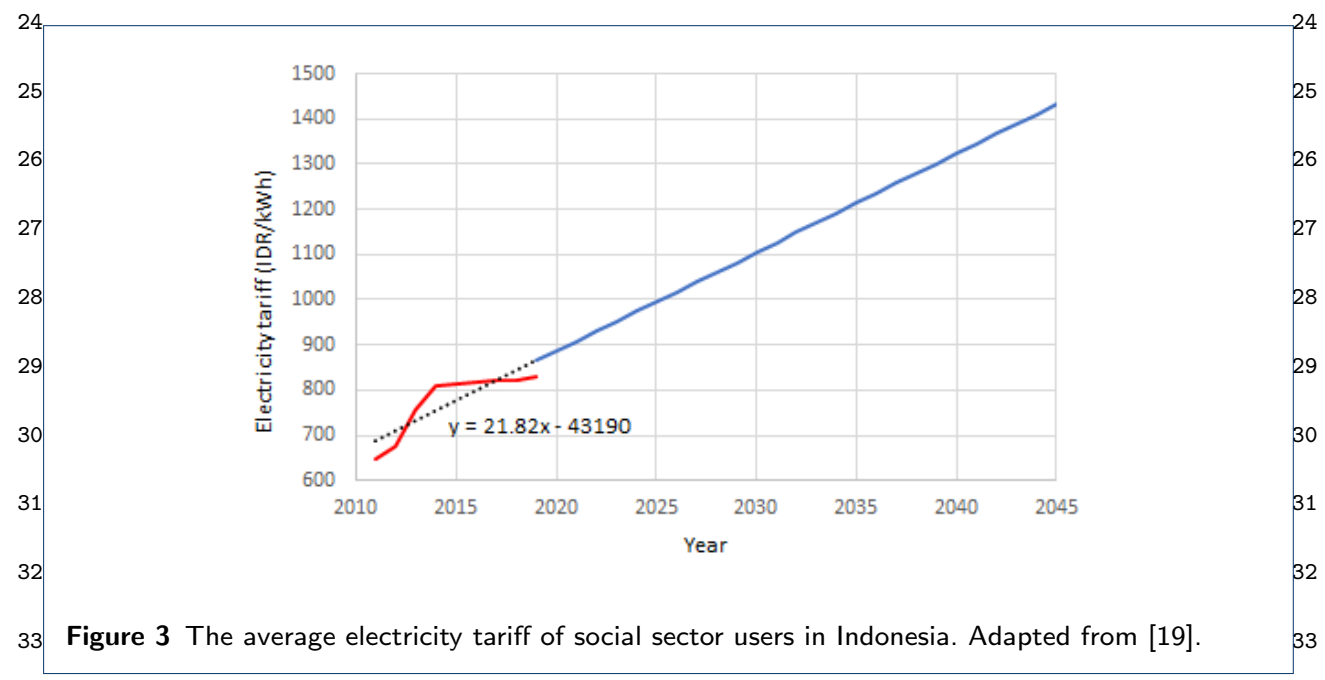




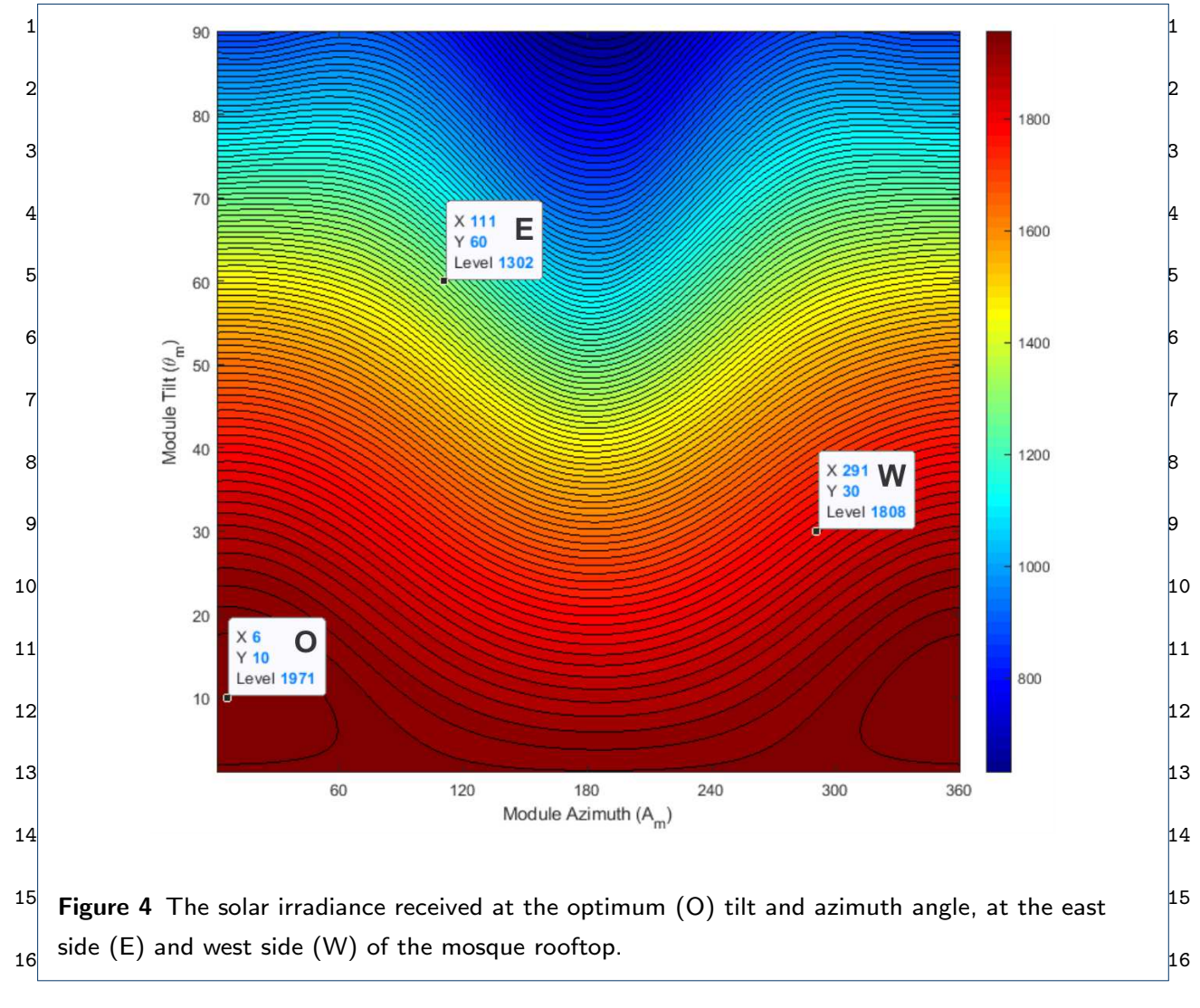

${ }^{18}$ loss at around $16 \%$. The annual minimum usage limit of the mosque is at $2640 \mathrm{kWh},{ }^{18}$ ${ }^{19}$ which is also equal to half of the mosque's annual load demand. Thus, these PV ${ }^{19}$ ${ }^{20}$ systems only employ half as much number of panels with capacities ranging from ${ }^{20}$ ${ }^{21} 1950$ to $2220 \mathrm{Wp}$. These results suggest that, under the current regulation, $\mathrm{PV}^{21}$ ${ }^{22}$ system with lower capacity can deliver a larger portion of the generated electricity ${ }^{22}$ ${ }^{23}$ to user.

${ }^{26}$ Climate Transparency [20] estimated that approximately 761 gram of carbon diox- ${ }^{26}$ ${ }^{27}$ ide are emitted to the air in order to generate $1 \mathrm{kWh}$ of electricity in Indonesia. ${ }^{27}$ ${ }^{28}$ Without using the PV system, the annual use of electricity at the Ontowiryo Mosque ${ }^{28}$ ${ }^{29}$ produces an emission of approximately 4017 kilograms of carbon dioxide. The Envi- ${ }^{29}$ $30 \quad 30$ ronmental Protection Agency [21] uses three sets of social cost estimates of carbon ${ }^{31}$ emissions with different discount levels, as can be seen in . This cost measures the ${ }^{31}$ ${ }^{32}$ negative impact of carbon emission on the environment from various externalities. ${ }^{32}$ 


\begin{tabular}{|c|c|c|c|c|c|c|c|}
\hline \multirow[b]{2}{*}{3} & \multirow{2}{*}{$\begin{array}{l}\text { Discount } \\
\text { Factor }\end{array}$} & \multicolumn{6}{|c|}{ Year } \\
\hline & & 2020 & 2025 & 2030 & 2035 & 2040 & 2045 \\
\hline 4 & $5.00 \%$ & 12 & 14 & 16 & 18 & 21 & 23 \\
\hline 5 & $3.00 \%$ & 42 & 46 & 50 & 55 & 60 & 64 \\
\hline & $2.50 \%$ & 62 & 68 & 73 & 78 & 84 & 89 \\
\hline
\end{tabular}

Based on the pricing above, the present value for the entire social cost of carbon emissions for 25 years, if the mosque does not use a PV system, is between 9 11.14 million and 50.51 million IDR. The use of PV system can reduce the amount 10 of carbon emission and the social cost by $50 \%$ with using the partial supply PV 11 system, and by $100 \%$ when the PV system completely supply the load demand. 12 When incorporated, the saving from emission social cost reduction can increase 13 the financial attractiveness of the PV systems when compared to the carbon inten14 sive fossil fueled power plants. It is important to note that the financial benefit of $15 \quad 15$ carbon emission reduction is not directly received by the PV system users under 16 the currently implemented regulation. Nonetheless, it is also important to highlight 17 the carbon emission reduction benefit as it helps the government to achieve the 18 Nationally Determined Contribution goal and preserve the nature.

19

${ }^{20} 4.4$ Financial Analysis ${ }^{21}$ The results of the NPV analysis of the PV systems show negative numbers for all ${ }^{21}$ ${ }^{22}$ types of solar panels and both scenarios. This value varies with the lowest NPV at ${ }^{22}$ ${ }^{23} 129.43$ million IDR and the highest NPV at -53.77 million IDR for the first scenario, ${ }^{23}$ 24 and in the second scenario the value ranges between -49.31 and -7.5 million IDR $^{24}$ ${ }^{25}$ for the lowest and highest NPV. The result of the LCOE analysis shows that the ${ }^{25}$ ${ }^{26}$ costs is higher than the grid electricity tariff. The value ranges between 1452 and ${ }^{26}$ ${ }^{27} 2642 \mathrm{IDR} / \mathrm{kWh}$ for the first scenario and between 1324 and $2475 \mathrm{IDR} / \mathrm{kWh}$ for the ${ }^{27}$ 28 second scenario.

${ }^{29}$ From these analyses, it is found that solar PV panels with relatively lower price, ${ }^{29}$ ${ }^{30}$ normalized to their power rating and area, have better financial feasibility results ${ }^{30}$ ${ }^{31}$ and yield higher financial feasibility. REC 355 TP2S 72 has the lowest LCOE in ${ }^{31}$ ${ }^{32}$ both scenario and a relatively high NPV. The highest NPV of the PV system is ${ }^{32}$ ${ }^{33}$ achieved by using the REC 310NP Black and REC 325NP for the first and second ${ }^{33}$ 
${ }^{1}$ scenario, respectively.

${ }^{2}$ Increasing the capacity of the PV system will reduce the use of electricity from the ${ }^{2}$

${ }^{3}$ grid. Reduction of usage beyond the minimum usage limit incurs a negative effect ${ }^{3}$

${ }^{4}$ on the annual revenue of the PV systems. The final electricity bill after using the ${ }^{4}$

${ }^{5} \mathrm{PV}$ system is equal to the minimum electricity bill for any usage lower than or ${ }^{5}$

${ }^{6}$ equal to the minimum usage limit. In other words, at higher capacity of PV system, ${ }^{6}$

${ }^{7}$ the amount of bill saving is capped at a maximum. On the other hand, the annual ${ }^{7}$

${ }^{8} \mathrm{OPEX}$, which is a function of the capacity of the PV system, continues to increase. ${ }^{8}$

${ }^{9}$ Thus, the revenue, that is calculated by subtracting the annual OPEX from the ${ }^{9}$

${ }^{10}$ annual bill saving, is decreasing at higher capacity of PV system. This condition ${ }^{10}$

${ }^{11}$ explains why the PV system in the first scenario have lower annual revenue than ${ }^{11}$

${ }^{12}$ those in the second scenario. 12

$13 \quad 13$

${ }^{14} \mathbf{5}$ Sensitivity on Regulatory Impact 14

${ }^{15} 5.1$ Abolishment of Monthly Minimum Usage 15

${ }^{16}$ The financial feasibility study finds that the current regulation on the minimum ${ }^{16}$

${ }^{17}$ usage limit for electricity from the grid incurs a detrimental effect on the PV sys- $^{17}$

${ }^{18}$ tems' financial attractiveness at higher capacities. Therefore, in this scenario, the ${ }^{18}$

${ }^{19}$ minimum monthly electricity usage from the grid is abolished while its impact on ${ }^{19}$

${ }^{20}$ the PV systems' financial feasibility is studied. Such support policy has been tem- ${ }^{20}$

${ }^{21}$ porarily implemented in August 2020 through the Ministerial Decree of the Ministry ${ }^{21}$

${ }^{22}$ of Energy and Mineral Resources Number 139K/26/MEM/2020 to deal with the ${ }^{22}$

${ }^{23}$ impact of COVID-19. ${ }^{23}$

${ }^{24}$ The impact of this regulation adjustment can be observed in figure 5 . The REC $355^{24}$

${ }^{25}$ TP2S 72 solar PV panel is taken as an example in this figure. It can be seen in this ${ }^{25}$

${ }^{26}$ figure that the amount of annual revenue increases along with the increase in the ${ }^{26}$

${ }^{27}$ number of panels and the capacity of the PV system before finally decreases after ${ }^{27}$

${ }^{28}$ the netload is lower than or equal to the annual minimum usage limit, $2640 \mathrm{kWh}{ }^{28}$

${ }^{29}$ The negative slope occurs as the annual bill saving is capped beyond this minimum ${ }^{29}$

${ }^{30}$ limit, as explained in subsection 4.3, while the annual OPEX grows $\quad 30$

${ }^{31}$ Meanwhile, in a scenario without the minimum usage limit, annual revenue in- ${ }^{31}$

${ }^{32}$ creases along with the number of solar panels to the point where the net load is ${ }^{32}$

${ }^{33}$ equal to zero. This change of regulation also increases the NPV of the PV in the ${ }^{33}$ 


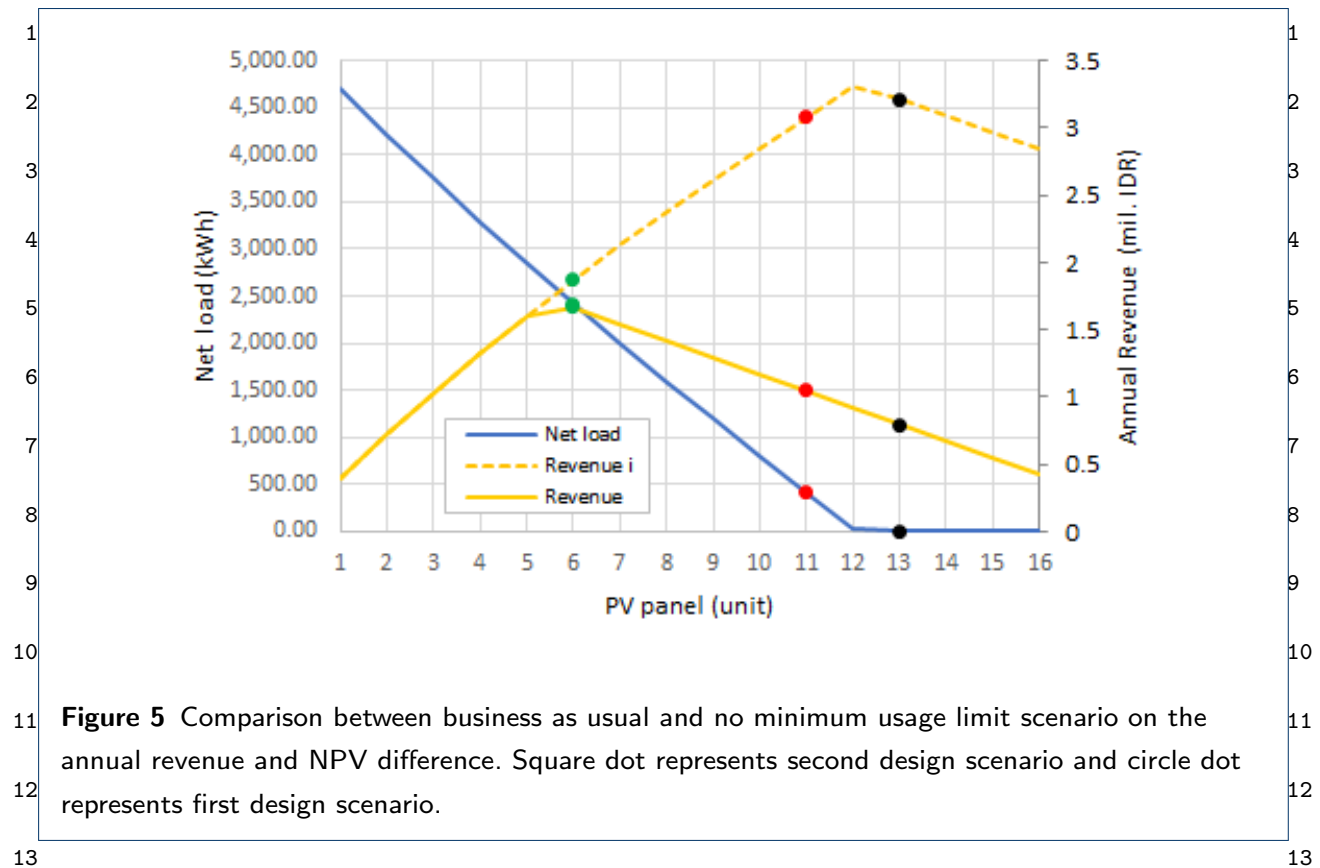

${ }^{14}$ first scenario for all types of the used solar PV panels. Figure 5 also shows in detail ${ }^{14}$ ${ }^{15}$ the increase of NPV at different number of PV panels employed in the PV system.

${ }^{16}$ At higher capacity PV system, the increase of NPV is capped at around 35 million ${ }^{16}$ 17 IDR, which occurs when the net load reaches zero.

${ }^{18}$ The PV systems in the second scenario that only partially meet the load demand ${ }^{18}$ ${ }^{19}$ does not earn as much increase in their NPV as their net load is only slightly ${ }^{19}$ ${ }^{20}$ lower than or equal to the minimum usage limit. For PV systems in this design ${ }^{20}$ 21 scenario, the increase of NPV results in the increase of capital expenditure recovery ${ }^{22}$ that ranges between $0.05 \%$ and $10 \%$. Meanwhile for the complete supply design ${ }^{22}$ 23 scenario, the increase of capital expenditure recovery is significantly higher as it ${ }^{24}$ ranges between $23.9 \%$ and $48.5 \%$. However, despite the increase of NPV, the PV ${ }^{24}$ ${ }^{25}$ systems that is designed to completely supply the load demand still have negative ${ }^{25}$ ${ }^{26} \mathrm{NPV}$ and lower than those that supply partially. 27

${ }^{28} 5.2$ Rework of the Net-Metering Scheme 28 ${ }^{29}$ Currently only $65 \%$ of the exported electricity from the PV system will be com- ${ }^{29}$ ${ }^{30}$ pensated by the government. This decision is made by considering the transmission ${ }^{30}$ ${ }^{31}$ and distribution costs as well as the line losses of the grid system that accounts for ${ }^{31}$ ${ }^{32} 38 \%$ of the grid electricity tariff [22]. In this sensitivity analysis, the net metering ${ }^{32}$ ${ }^{33}$ scheme is reworked so that $100 \%$ of the exported energy from the PV system to the 


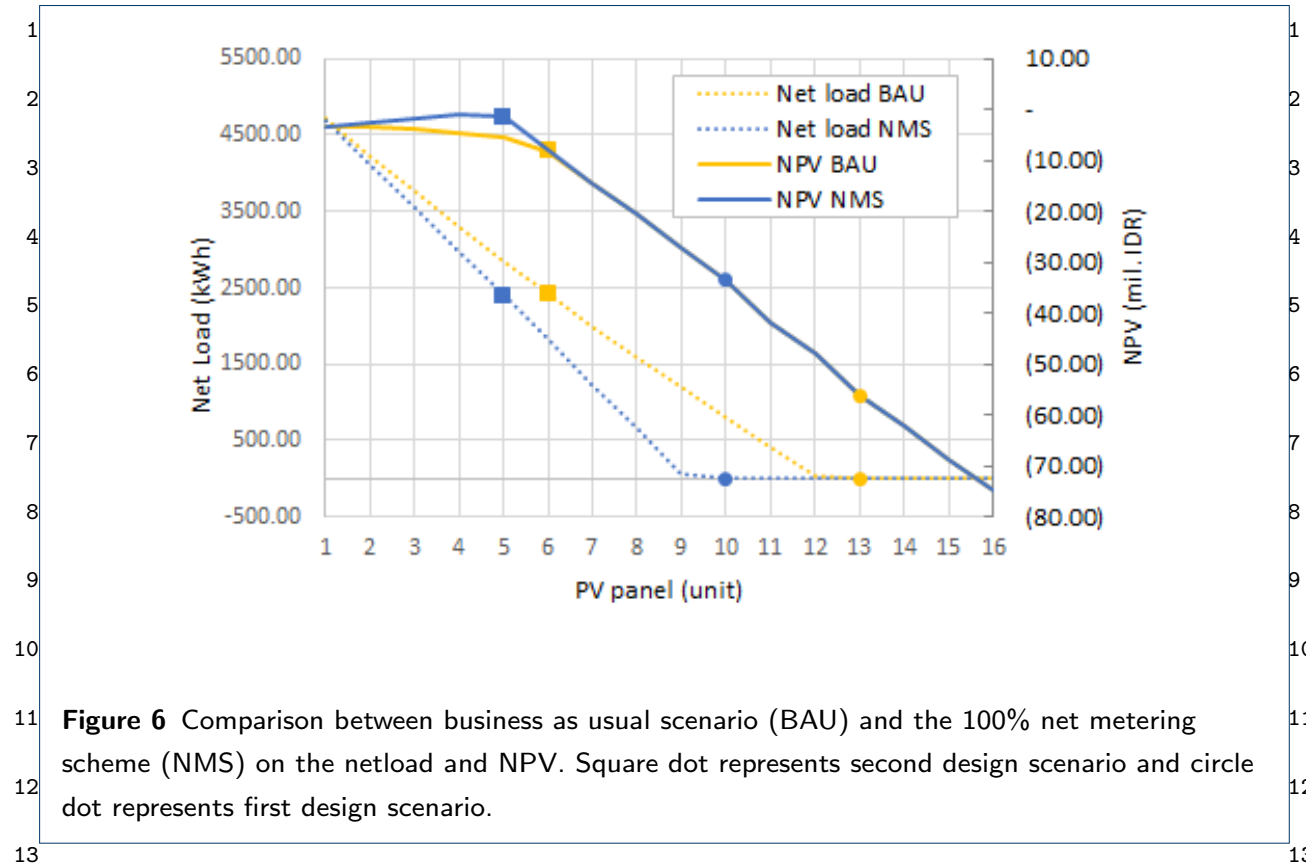

14 grid will be compensated.

15 The result shows that with this scenario, $\mathrm{PV}$ systems require smaller number of 16 PV panels to either partially or completely meet the load demand of Ontowiryo 17 Mosque, shown in figure 6. This condition leads to lower CAPEX, higher revenue 18 and higher NPV. The NPV increase ranges between 19.5 and 40.8 million IDR ${ }^{19}$ for the PV system that completely supplies the load demand and between 5.7 and 20 11.9 million IDR for the PV system in the second modelling scenario that partially 21 supplies the load demand. The increase of NPV also results in higher capital expen22 diture recovery that ranges between $20 \%$ and $40 \%$ for the complete supply scenario 23 and between $15.3 \%$ and $21.4 \%$ for the partial supply scenario. Despite the increase, 24 the NPV of all PV systems still yields negative values.

25

${ }^{26} 5.3$ Higher Electricity Tariff

${ }^{27}$ The non-subsidized tariff is taken from the average electricity generation basic cost ${ }^{27}$ ${ }^{28}$ provided in the PLN statistics 2019 and shown in figure 7 [19]. It is estimated that ${ }^{28}$ ${ }^{29}$ the non-subsidized tariff in 2021 and 2045 are at 1428 and $2205 \mathrm{IDR} / \mathrm{kWh}$. respec- ${ }^{29}$ ${ }^{30}$ tively. The result shows that higher electricity tariff scales up the annual revenue 30 1. ${ }^{31}$ The increase of NPV for all PV systems is capped at 19 million IDR due to the ${ }^{31}$ ${ }^{32}$ annual grid electricity minimum usage limit. Despite the increase, PV system that ${ }^{32}$ 33 33 completely supplies the load demand still have negative values of NPV. 


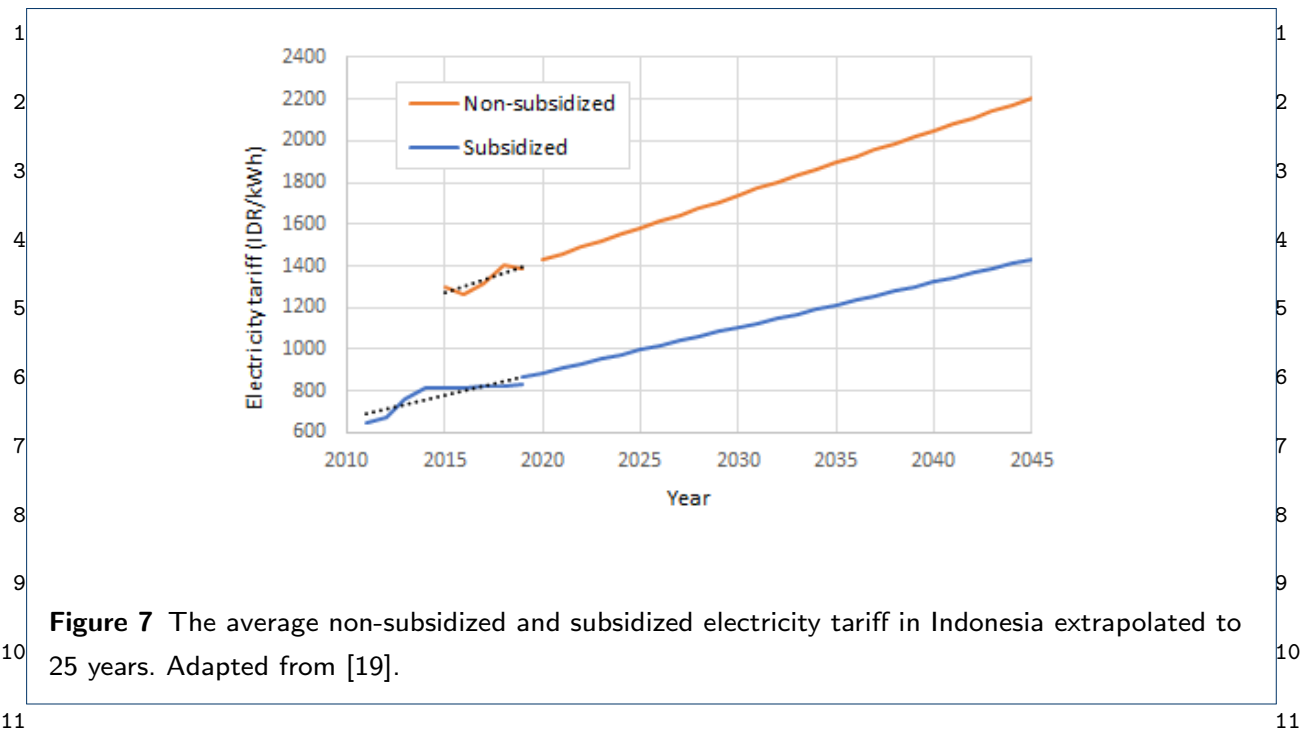

12

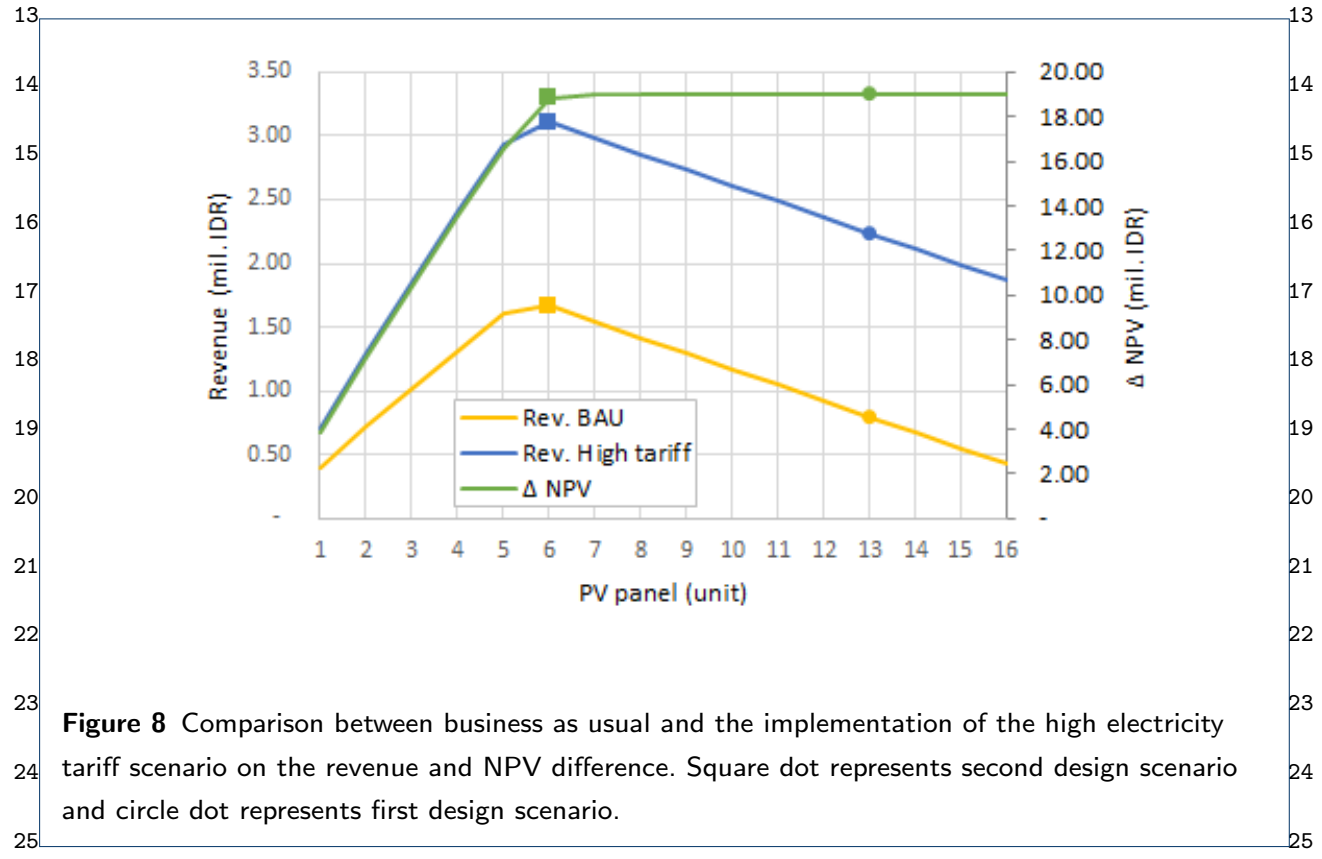

26

${ }^{28}$ On the other hand, when compared to other supportive measures, the implemen- ${ }^{28}$ 29 tation of higher electricity tariff results in the highest NPV increase for PV systems

${ }^{30}$ in the second scenario. The increase of NPV results in the increase of capital expen 30

${ }^{31}$ diture recovery that ranges between $26.5 \%$ and $59 . \%$. As for the complete supply ${ }^{31}$

${ }^{32}$ design scenario, the increase of capital expenditure recovery ranges between $13.6^{32}$ and $28.4 \%$. 
${ }^{1} 6$ Conclusion 1

${ }^{2}$ In this paper, we have assessed the design of rooftop PV system on mosque and ${ }^{2}$

${ }^{3}$ its economic implications. Our results show that the use of PV system allows $a^{3}$

${ }^{4}$ reduction of carbon emission as the power generation in Indonesia is dominated by ${ }^{4}$

${ }^{5}$ the carbon-intensive power plants. This reduction also provides an indirect financial ${ }^{5}$

${ }^{6}$ benefit that, when incorporated, can add leverages for the adoption of PV systems ${ }^{6}$

${ }^{7}$ as an eco-friendly option to generate power.

${ }^{8}$ Despite the carbon reduction benefit, at the current electricity tariff and capital ${ }^{8}$

${ }^{9}$ costs of the components, and the implemented regulations around the adoption of ${ }^{9}$

${ }^{10} \mathrm{PV}$ system, it is financially unfeasible to install a rooftop PV system on a mosque. ${ }^{10}$

${ }^{11}$ The subsidized tariff of electricity results in lower annual electricity bill saving, ${ }^{11}$

${ }^{12}$ which is the means of the PV system to recover its capital investment. The reg- ${ }^{12}$

${ }^{13}$ ulation on the minimum grid electricity usage limit prevents user to install high ${ }^{13}$

${ }^{14}$ capacity PV systems due to the capped revenue and the increasing OPEX at higher ${ }^{14}$

${ }^{15}$ capacity. This condition leads to our finding that PV systems with partial supply ${ }^{15}$

${ }^{16}$ scenario have better financial attractiveness than the PV system that completely ${ }^{16}$

${ }^{17}$ supply the load demand of the mosque. Intervention on the prevailing regulations ${ }^{17}$

${ }^{18}$ such as rework on net-metering scheme and implementation of higher electricity ${ }^{18}$

19 tariff may increase the financial attractiveness of the PV systems. 19

${ }^{20}$ Thus, the result of this paper should serve policy makers as a reflection for the ${ }^{20}$

${ }^{21}$ prevailing regulation on the adoption of PV in the power sector. This paper pro- ${ }^{21}$

${ }^{22}$ vides an insight that the plan of increasing the share of renewable sources to $23 \%{ }^{22}$

${ }^{23}$ in the power generation by the year of 2025 can be hampered by the prevailing ${ }^{23}$

${ }^{24}$ regulation. A more detailed exploration on the components of the PV system, es- ${ }^{24}$

${ }^{25}$ pecially those that are available locally, can enrich the study with a higher degree ${ }^{25}$

${ }^{26}$ of context to the condition in Indonesia. Further analysis in this direction may lead ${ }^{26}$

${ }^{27}$ to higher financial attractiveness of the PV systems as it cuts down the shipping ${ }^{27}$

${ }^{28}$ cost in the procurement process. The need for further exploration is also supported ${ }^{28}$

${ }^{29}$ by the large diversity of worship facilities from various beliefs in Indonesia. In some ${ }^{29}$

${ }^{30}$ parts of the country, there are still many worship facilities with low socio-economic ${ }^{30}$

${ }^{31}$ condition which require an eco-friendly means to be independent in meeting their ${ }^{31}$

32 energy needs. 
${ }^{1}$ Acknowledgements 1

${ }_{2}$ The authors would like to thank Dr. Desti Alkano and Grace Peranginangin from Energy Academy Indonesia for 2 their feedback.

3

Funding

4 This research was done with the funding and support of the Master of Architecture UII. 4

5

Availability of data and materials

6The datasets supporting the conclusions of this article are available in the Solcast Toolkit repository, [DOI : 6

$7^{10.25911 / 5 c 073 \mathrm{e} 713 \mathrm{e} 5 \mathrm{dd}, \text { https://solcast.com] }} 7$

${ }_{8}$ Competing interests 1

The authors declare that they have no competing interests.

Authors' contributions

${ }^{10}$ The present study was carried out in collaboration between both the authors. FAQ designed, performed, analyzed, 10

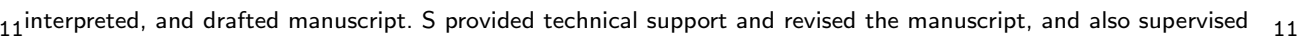
the research. Both the authors read and approved the final manuscript.

12

Author details

${ }^{13}$ Department of Architecture, Universitas Islam Indonesia, Yogyakarta, Indonesia. ${ }^{2}$, Smart Energy Indonesia, 13

14 Yogyakarta, Indonesia.

15References 15

1. UNFCCC. First Nationally Determined Contribution - Republic of Indonesia. UNFCCC; 2016.

16 2. Dewan Energi Nasional. Catatan Akhir Tahun: Transisi Energi Indonesia Sampai Dimana?; 2020 [cited 16

17 12-02-2021]. Available from: https://den.go.id/index.php/dinamispage/index/974-catatan-akhir-tahun-transisi- 17 energi-indonesia-sampai-dimana.html.

18 3. Tawalbeh M, Al-Othman A, Kafiah F, Abdelsalam E, Almomani F, Alkasrawi M. Environmental impacts of 18

19 solar photovoltaic systems: A critical review of recent progress and future outlook. Science of The Total 19 Environment. 2020;759:61-81.

20 4. IESR. Indonesia Clean Energy Outlook: Tracking Progress and Review of Clean Energy Development in 20 Indonesia. Institute for Essential Services Reform; 2019.

21

5. Suparwoko. Detail Engineering Design of the Ontowiryo Mosque Purworejo, Central Java. FTSP UII; 2018.

22 6. Ministry of Religion. SIMAS: Mosque Information System home page; 2020 [cited 12-02-2021]. Available from:22 https://simas.kemenag.go.id/.

23 7. Ghazali AM, Ubaid A, Wardhana AR, Masud I, Mohammad J, Ma'afi M, et al. Fikih Energi Terbarukan: 23

24 Pandangan dan Respons Islam atas Pembangkit Listrik Tenaga Surya (PLTS). Jakarta-Yogyakarta: 24 LAKPESDAM-PBNU; 2017.

25 8. Mustinda L. Surat Al Kautsar, Legkap Arti Mana dan Keutamaannya; 2019 [cited 12-02-2021]. Available from:25

26 https://news.detik.com/berita/d-4757722/surat-al-kautsar-lengkap-arti-makna-dan-keutamannya. 26

9. Rashid EE, Alwi SRW, Mana ZA. Evaluation of Photovoltaic System Installation for a Mosque in Universiti

27 Teknologi Malaysia. PERINTIS e-Journal. 2011;p. 61-81. 27

10. Almutairi YB. Peak Shaving Using Grid-Connected Solar Panels Case Study: Ministry of Islamic Affairs 28 Mosque. Journal of Engineering Research and Applications. 2018;p. 158-166.

2911. Elshurafa AM, Alsubaie AM, Alabduljabbar AA, Al-Hsaien SA. Solar PV on mosque rooftops: Results from a 29 pilot study in Saudi Arabia. Journal of Building Engineering. 2019;.

${ }^{30}$ 12. Ministry of Energy and Mineral Resources. Ministerial Regulation of Energy and Mineral Resources number $49{ }^{30}$

31 year 2018: Use of Rooftop Solar Power Generation Systems by Consumers of PT Perusahaan Listrik Negara 31 (Persero). Ministry of Energy and Mineral Resources; 2018.

3213. Solcast. Solar Irradiance Data; 2018. Available from: https://solcast.com/ [cited 23-09-2020]. 32

33 14. Smets A, Jäger K, Isabella O, Swaaij RV, Zeman M. Solar Energy: The physics and engineering of photovoltaic ${ }_{33}$ conversion, technologies and systems. Delft: UIT Cambridge Ltd.; 2016. 
${ }^{1} 15$. Ministry of Energy and Mineral Resources. Ministerial Regulation of Energy and Mineral Resources number $28{ }^{1}$

2 year 2016: the tariff for electricity provided by PT Perusahaan Listrik Negara (Persero). Ministry of Energy and 2 Mineral Resources; 2016.

316. IRENA. Renewable Power Generation Costs in 2019. International Renewable Energy Agency; 2019.

41. IEA. World Energy Investment 2020. International Energy Agency; 2020.

18. Steffen B. Estimating the cost of capital for renewable energy projects. Energy Economics. 2020;.

519. PT PLN (Persero). Statistik PLN 2019. PT PLN (Persero); 2020.

20. Climate Transparency. Brown to Green: The G20 transition towards a net-zero emission economy. Climate

6 Transparency; 2019.

721. EPA. EPA Fact Sheet: Social Cost of Carbon. Environmental Protection Agency; 2016.

22. Hamdi E. Indonesia's Solar Policies: Designed to Fail. The Institute for Energy Economics and Financial 8 Analysis; 2019. 


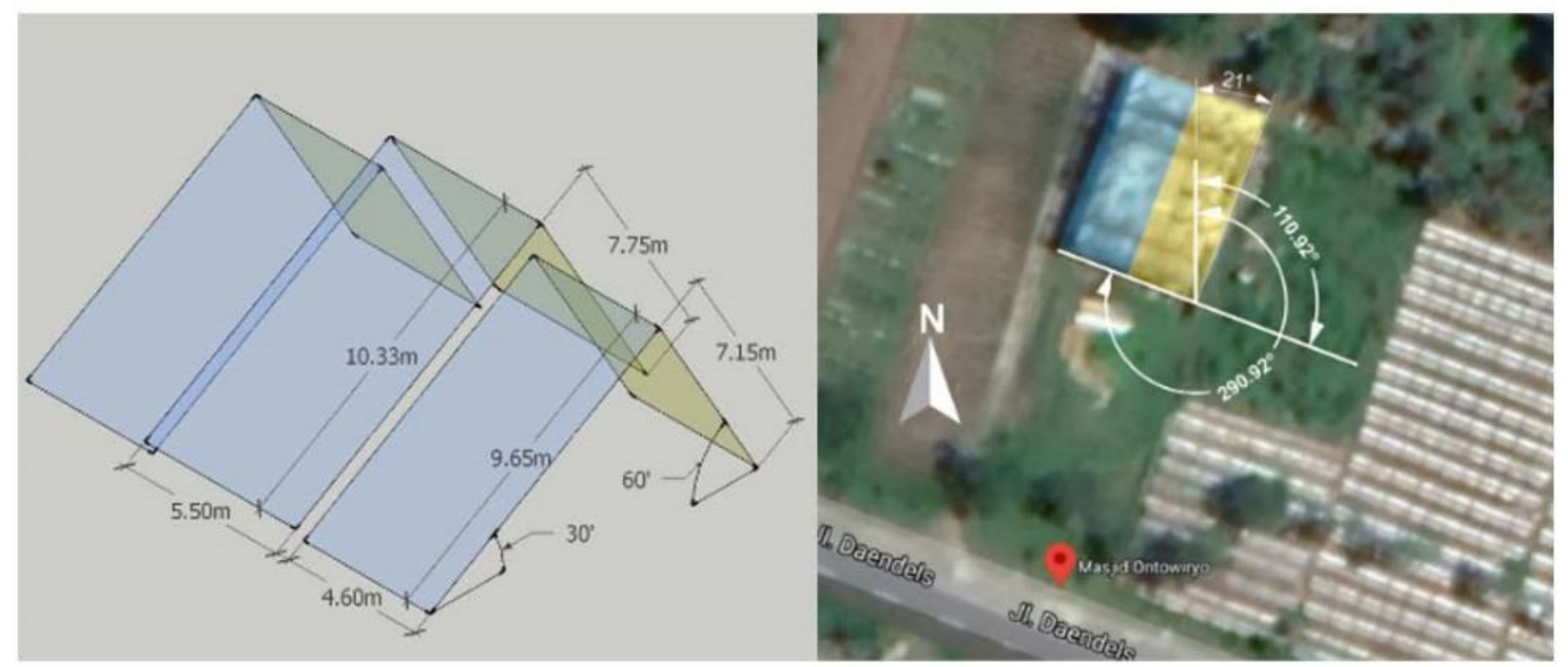

\section{Figure 1}

"Please see the Manuscript PDF file for the complete figure caption". Note: The designations employed and the presentation of the material on this map do not imply the expression of any opinion whatsoever on the part of Research Square concerning the legal status of any country, territory, city or area or of its authorities, or concerning the delimitation of its frontiers or boundaries. This map has been provided by the authors. 


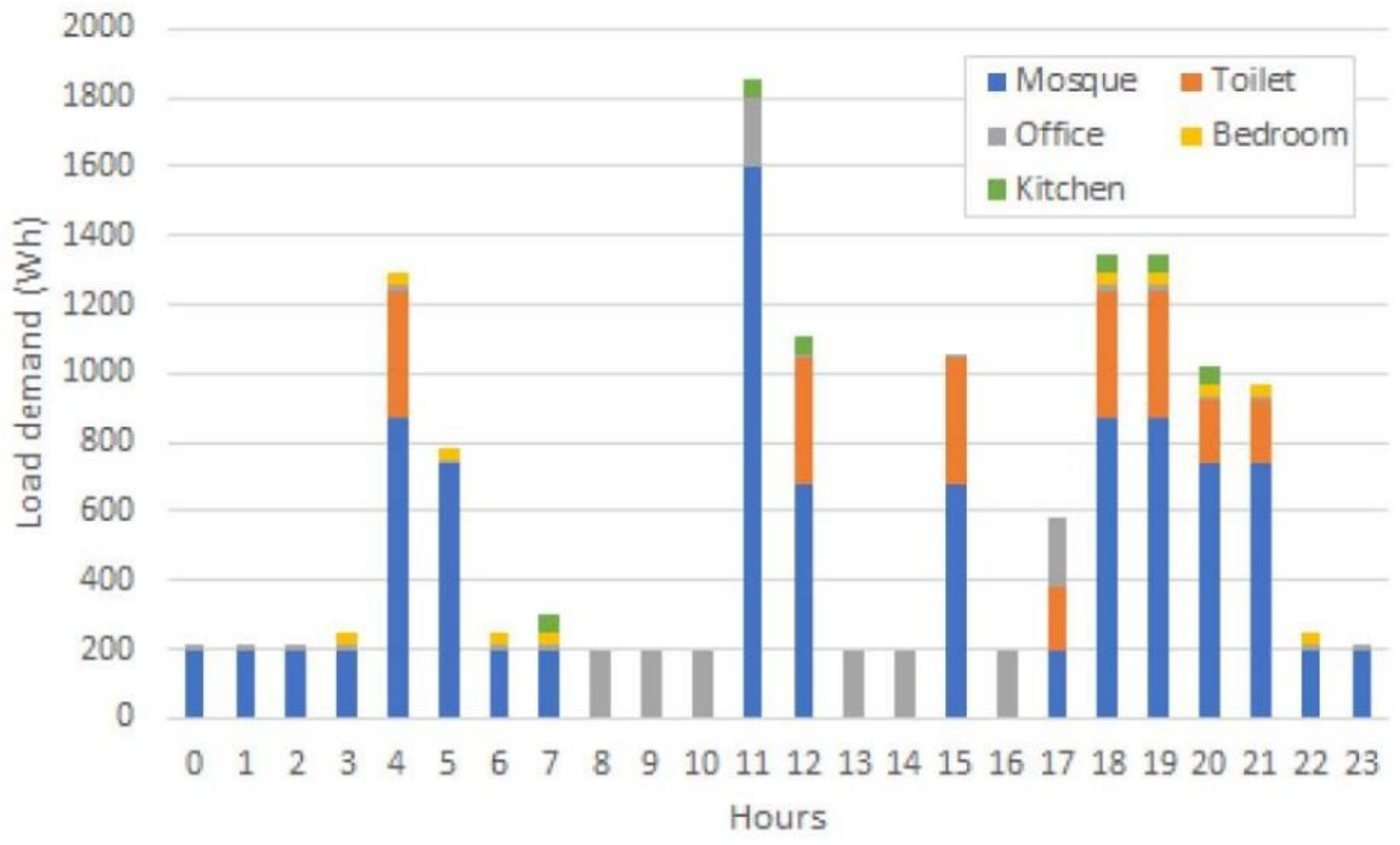

Figure 2

The hourly load demand profile of Ontowiryo Mosque.

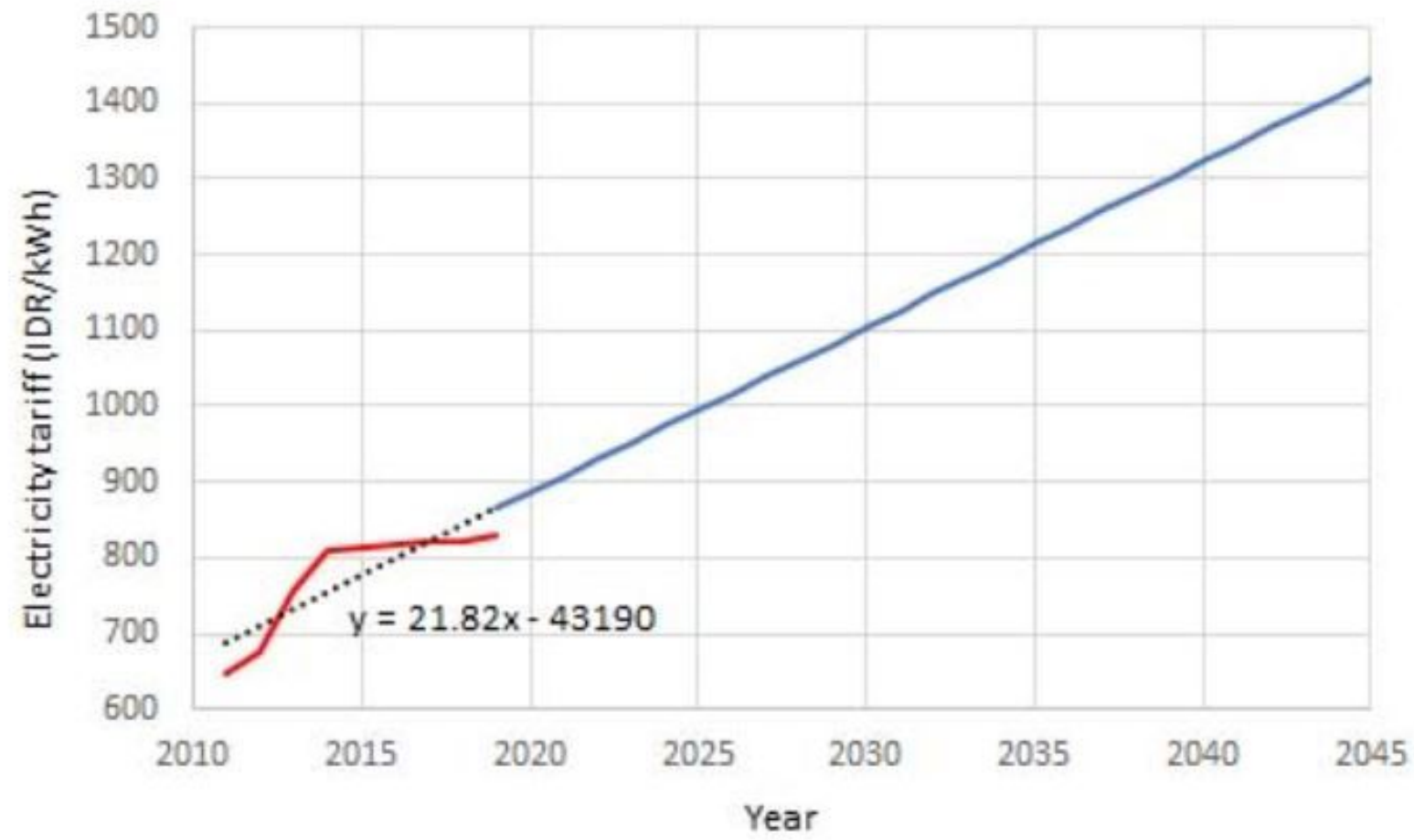

Figure 3 
The average electricity tariff of social sector users in Indonesia. Adapted from [19].

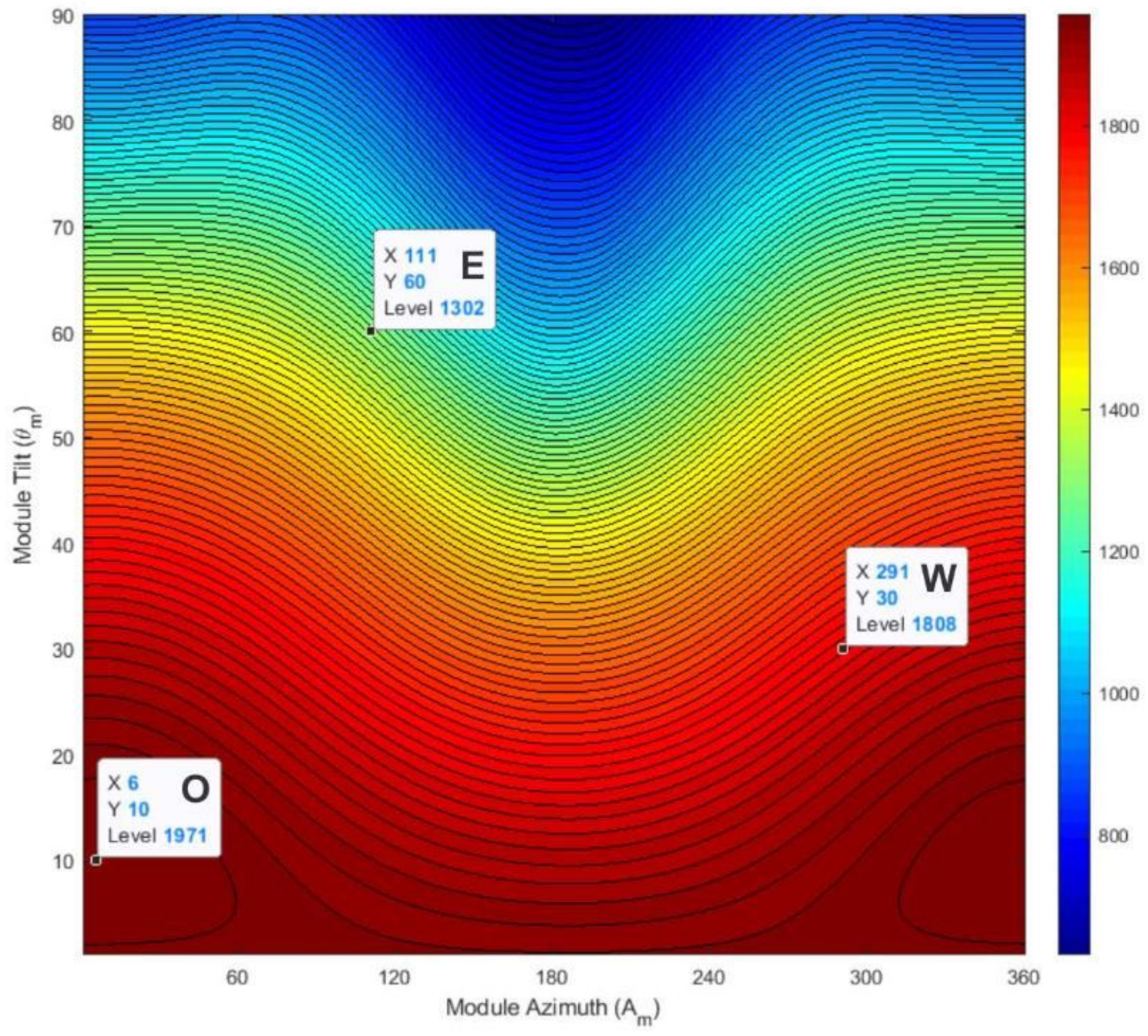

Figure 4

"Please see the Manuscript PDF file for the complete figure caption". 


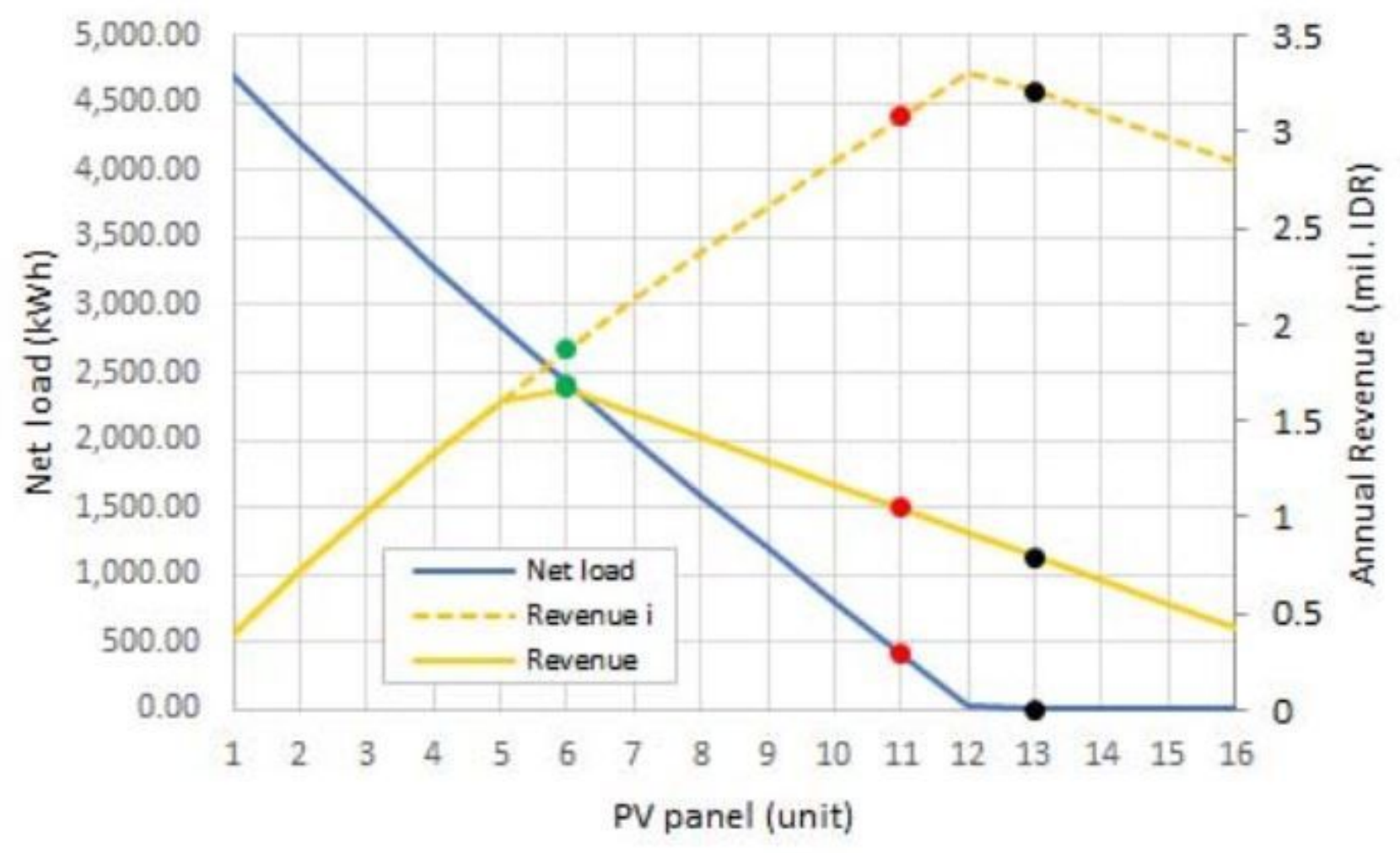

Figure 5

"Please see the Manuscript PDF file for the complete figure caption". 


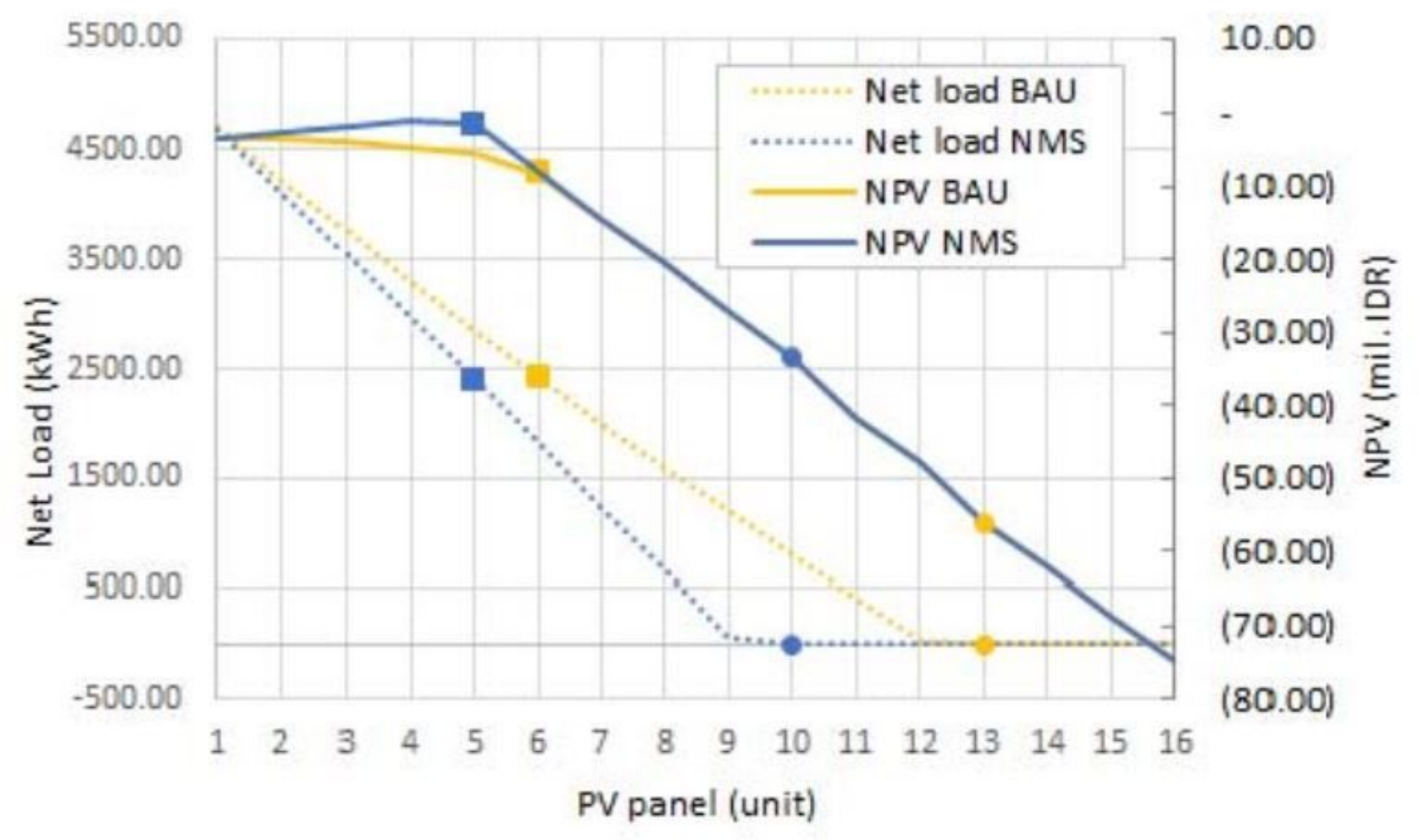

Figure 6

"Please see the Manuscript PDF file for the complete figure caption". 


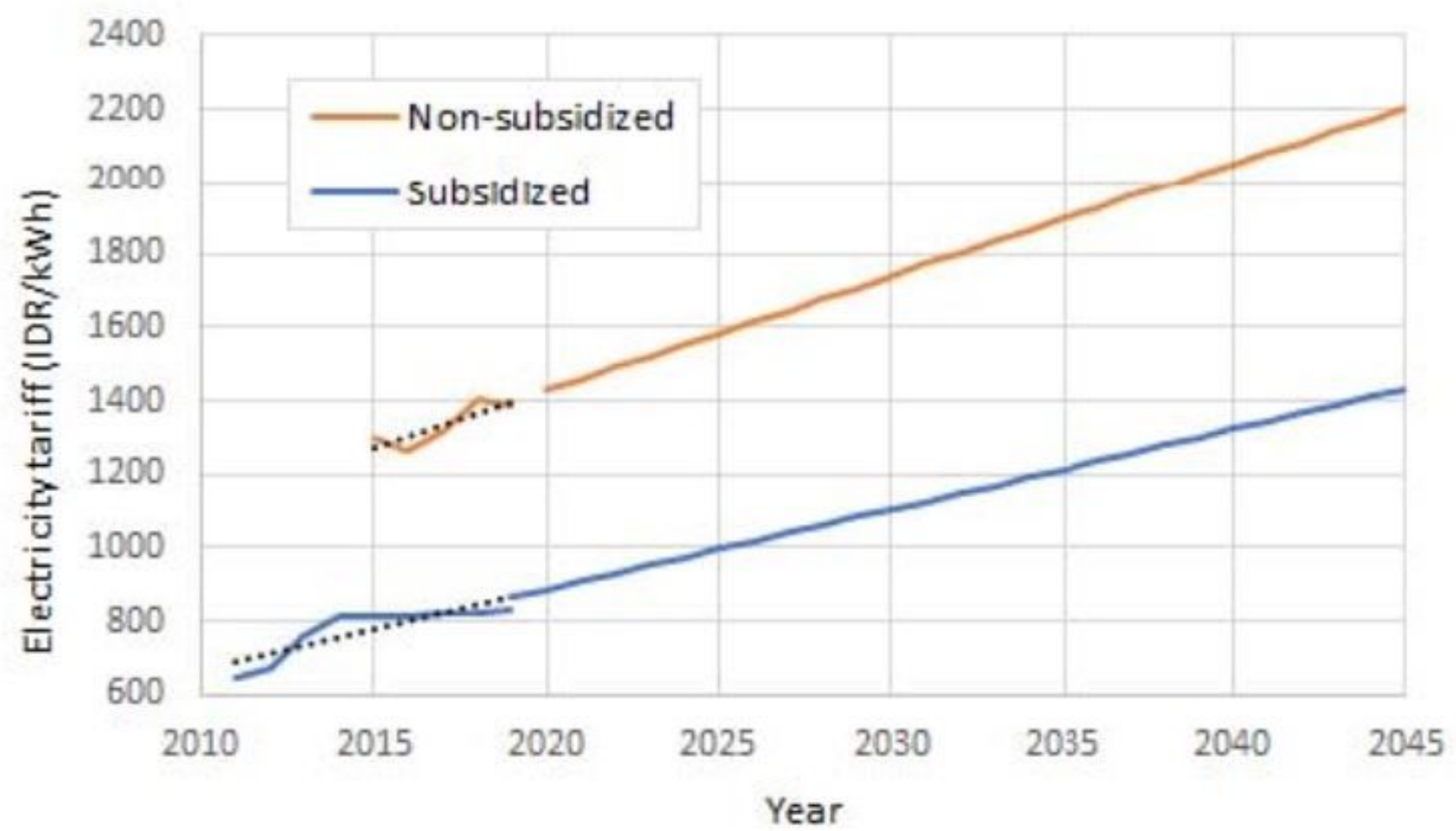

Figure 7

"Please see the Manuscript PDF file for the complete figure caption". 


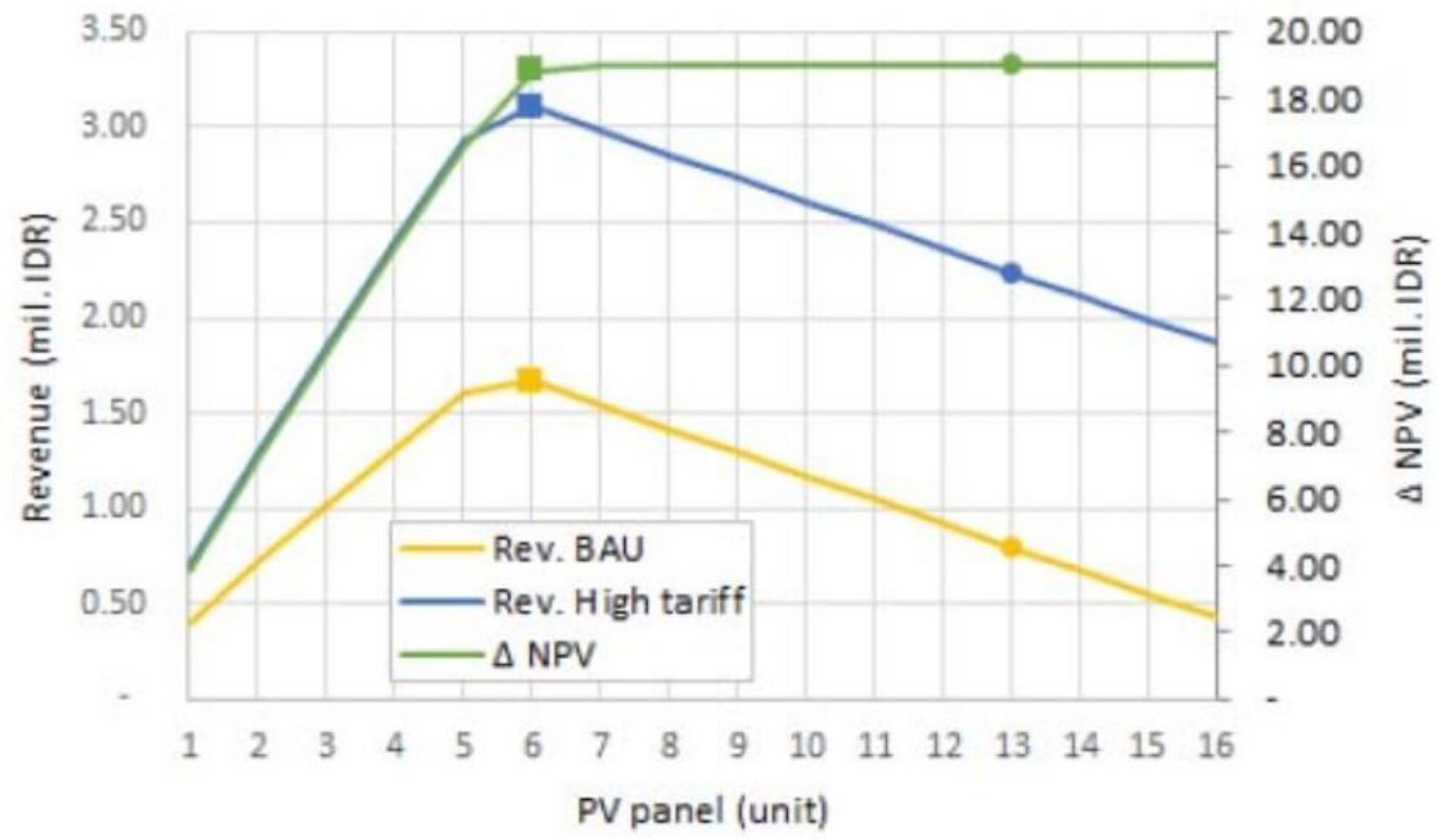

Figure 8

"Please see the Manuscript PDF file for the complete figure caption". 